\title{
Effect of Partial Shade and Weeding Intervals on Growth and Yield Performance of Chilli (Capsicum frutescens L.) in Dry Zone of Sri Lanka
}

\author{
G. Asharp (Corresponding Author) \\ Department of Agronomy, Faculty of Agriculture, University of Jaffna, Sri Lanka \\ Tel: 0094772913367 E-mail: asharpsharmec9@gmail.com \\ S. Sivachandiran \\ Department of Agronomy, Faculty of Agriculture, University of Jaffna, Sri Lanka \\ E-mail: ssivamathy@yahoo.com
}

Received: November 12, 2018

Accepted: November 22, 2018

doi:10.5296/jas.v6i4.13880

URL: https://doi.org/10.5296/jas.v6i4.13880

\begin{abstract}
Chilli (Capsicum frutescens L.) is one of the most important cash crop cultivated in the Sri Lanka. Though, chilli cultivation has been tremendously influenced by the adverse climatic conditions and weed infestations. To solve these issues, a field experiment was conducted at Integrated Farm and Training Center, Faculty of Agriculture, University of Jaffna, Kanagarayankulam, during February 2017 to July 2017, to evaluate the impact of partial shade and effect of different weeding intervals on growth and yield performance of chilli. The treatments consisted of two shade levels (partial shade and full sun) and four weeding intervals (weeding at one week, two week, three week intervals and no weeding) in split plot arrangement with three replicates. Light intensity was statistically significant $(\mathrm{p}<0.05)$ between shade levels. The lowest light intensity and the highest relative humidity were recorded in partially shaded treatment as 22.50 klux and $85.42 \%$, respectively at 8.00 a.m. Weed density was significantly $(\mathrm{p}<0.05)$ differed by shade and weeding interval treatments. The lowest weed density was recorded in full sun (control) and weeding at one week interval treatment. Shade treatments and weeding interval treatments have shown a significant $(\mathrm{p}<$ 0.05) effect on plant height, leaf numbers, leaf length, fruit length, fruit fresh weight and total yields. Partial shade and weeding at one week interval have shown significantly higher growth and yield performance compared to the other levels of treatment. Therefore, these results can be recommended for adoption by the farmers to improve the performance of chilli.
\end{abstract}

Keywords: climatic conditions, chilli, dry zone, partial shade, weeding interval 


\section{Introduction}

Chilli (Capsicum frutescens L.) has its unique place in Asian diet a spice as well as a vegetable. It is also a high value crop commercially grown in Sri Lanka (Gunawardena and De Silva, 2014). It occupies an important place in the human culture since pre-history in many countries. Capsicum is well known in the pre-historic Mexican culture such as Aztecs and Olmecas. Capsicum belongs to the family Solanaceae possessing 10 species (Sarkar et al., 2007). Chilli is consumed as fresh, dried or powder throughout the world. It is rich in proteins, lipids, carbohydrates, fibres, mineral salts $(\mathrm{Ca}, \mathrm{P}, \mathrm{Fe})$ and in vitamins $\mathrm{A}, \mathrm{D}_{3}, \mathrm{E}, \mathrm{C}, \mathrm{K}$, $\mathrm{B}_{2}$ and $\mathrm{B}_{12}$ (Orobiyi et al., 2013).

Fluctuation of biotic and abiotic factors are critical challenges of climate change on good quality crop production (Easwaran et al., 2015). Wheeler et al (2000) reported that the global production of annual crops would be affected by the increases in mean temperatures of $2-4$ ${ }^{0} \mathrm{C}$ expected towards the end of the 21 st century. Furthermore, Godawatte et al (2011) stated that the output of Sri Lanka's dry zone agricultural would be decreased significantly in the next 20 to 30 years because of reduced rainfall and increased temperature. The extreme climatic conditions had been experienced in Northern Province, represented by above average ambient temperatures and below average rainfalls. Moreover, its groundwater-based cropping systems with high utilization of irrigation water from shallow aquifers makes farming activities vulnerable to climate change (Easwaran et al., 2016). Climate change will have greater negative impact on poor farm households in dry zone of Sri Lanka as they have a low adaptive capacity to climatic change. In spite of the technological advances made in improved crop management, irrigation, plant protection and fertilization, weather and climate remain the key factors of agricultural productivity in many countries. Whether farmers could use the innovative technology to adapt to the climate change, weed infestation and pest incidences is a crucial question (Dishani and De Silva, 2015).

The climate change will be the leading reason for recent changes observed throughout the world with in the weed spectrum in different cropping system, which leads to complex crop weed interaction (Ramesh et al., 2017). The agro climatic conditions, biotic and abiotic factors influence the growth and photosynthetic efficiency of the crop. The translocation of assimilates to the economical important parts results in big size fruits with higher fruit weight. As Capsicum is profitable commercial crop with high nutritional value extensive research had been carried throughout the world to increase the yield under unfavorable conditions (Sarkar et al., 2007).

Based on these facts, this study was carried out to evaluate the effect of partial shade and different weeding intervals as a fraction of package of practices to green chilli cultivation in dry zone of Sri Lanka. 


\section{Materials and Methods}

\subsection{Site Description}

A field study was conducted during February 2017 to July 2017 at Integrated Farm and Training Center, Faculty of Agriculture, University of Jaffna, Kanagarayankulam, which has a well-drained, clay loam soil. This study was initiated to evaluate the impact of partial shade and effect of different weeding intervals on growth and yield performance of chilli. The study area is located between $9^{\circ} 01^{\prime} \mathrm{N}$ latitude and $80^{\circ} 53^{\prime} \mathrm{E}$ longitudes at an elevation of $67 \mathrm{~m}$ above mean sea level. It consists of slightly sloppy topography and relatively flat land.

\subsection{Experimental Design and Treatment}

Experiment was carried out in a split plot design with three replications, shade treatments (partial shades, full sun) in main plots and weeding interval treatments (weeding at one week, two week and three week intervals and no weeding) in sub plot (Table 1). The dimension of each individual plot was $1.8 \mathrm{~m} \times 1.4 \mathrm{~m}$. Shade nets $(70 \%$ poly propylene black shade net) were supported with wooden posts forming a pyramidal structure with the highest point at 1.5 $\mathrm{m}$ along the center of the main plots and lowest point at $1 \mathrm{~m}$ along the edge of the main plots. Weeding treatments were executed by doing the weeding at one week, two week and three week intervals and no weeding (control). Manual weeding was practiced throughout the experiment.

Table 1. Treatment combinations

\begin{tabular}{clc}
\hline Main plot & \multicolumn{1}{c}{ Sub plot } & Treatment code \\
\hline \multirow{4}{*}{ Partial Shade } & Weeding at one week interval & $\mathrm{S}_{1} \mathrm{~W}_{1}$ \\
& Weeding at two week interval & $\mathrm{S}_{1} \mathrm{~W}_{2}$ \\
& Weeding at three week interval & $\mathrm{S}_{1} \mathrm{~W}_{3}$ \\
& No weeding & $\mathrm{S}_{1} \mathrm{~W}_{4}$ \\
\hline \multirow{4}{*}{ Full sun } & Weeding at one week interval & $\mathrm{S}_{2} \mathrm{~W}_{1}$ \\
(Control) & Weeding at two week interval & $\mathrm{S}_{2} \mathrm{~W}_{2}$ \\
& Weeding at three week interval & $\mathrm{S}_{2} \mathrm{~W}_{3}$ \\
& No weeding & $\mathrm{S}_{2} \mathrm{~W}_{4}$ \\
\hline
\end{tabular}

\subsection{Crop Establishment and Management}

Mould board ploughing and land levelling were applied. Chilli was raised in a nursery and thirty-day-old chilli seedlings (Variety $\mathrm{MICH}_{3}$ ) were transplanted in $60 \mathrm{~cm} \times 45 \mathrm{~cm}$ spacing. Water was applied by basin irrigation throughout the crop growing season. Fertilizer was applied according to the Department of Agriculture recommendation. Two rows of border crop (Sorghum sp) was established with the spacing of $30 \mathrm{~cm} \times 15 \mathrm{~cm}$ around the experimental site in order to reduce the pest and disease problems.

\subsection{Measurements and Data Collection}

Environmental measurements, growth measurements, weed density, weed dry matter and yield components were recorded during the vegetative, reproductive and maturity periods. 
Minimum and maximum light intensity, relative humidity and atmospheric temperature were measured in every treatments during 8.00 a.m., 12.00 p.m. and 4.00 p.m. at two week interval. Meanwhile, two plants were selected at random and used to count the number of leaves and used to measure the plant height and leaf length at two week interval. Weed infestations (weed density and weed dry weight) were evaluated at one week interval by counting and weighing (oven dry weight) the weeds in a $25 \mathrm{~cm} \times 25 \mathrm{~cm}$ quadrate per plot. Total yield, fruit length and average fruit fresh weight were calculated at the end of the experiment.

\subsection{Data Analysis}

The collected data were subjected to analysis of variance using the General Linear Model procedure of SAS (9.1.3). Different mean comparisons were carried out by Duncan multiple range test at $5 \%$ probability.

\section{Results and Discussion}

\subsection{Environmental Variables}

Light intensity of shaded chilli plant was significantly lower than those of chilli plants grown in direct sun light, whereas the relative humidity of the air of the shaded plants was significantly higher than of plants grown in full sun light except at 12.00 p.m. and 4.00 p.m. Atmospheric temperature did not differ significantly except at 8.00 a.m. (Figure 1). The lowest light intensity $(16.57 \mathrm{klux})$ and atmospheric temperature $\left(33.26{ }^{\circ} \mathrm{C}\right)$ were recorded in partially shaded treatment. Bote and Struik (2011) stated that the reduced air temperature was mainly due to the reduced direct incidence of solar radiation on the coffee canopy. Shading buffers the extreme temperature variations and provides a microclimate which attenuates extreme temperatures of air and soil and preserves surface soil humidity.

\subsection{Weed Density and Weed Dry Weight}

The emergence of weeds showed little difference among weeding interval treatments. The lowest weed density and weed dry weight were observed in weeding at one week interval treatment. Experiments tested without weeding showed comparatively higher weed density and weed dry weight as 284 number $/ \mathrm{m}^{2}$ and $1.22 \mathrm{~g} / \mathrm{m}^{2}$ respectively (Table 2 and 3). These results were similar to G/Mariam and Fufa (2016) who stated that there was an increase in weed population and biomass with an increase in weed-crop competition period. Increase in weed density and weed dry weight with prolonged competition period might be due to the extra time availed by weed to germinate, survive and continue growth. The interaction between the shade treatments and weeding interval treatments were insignificant. 

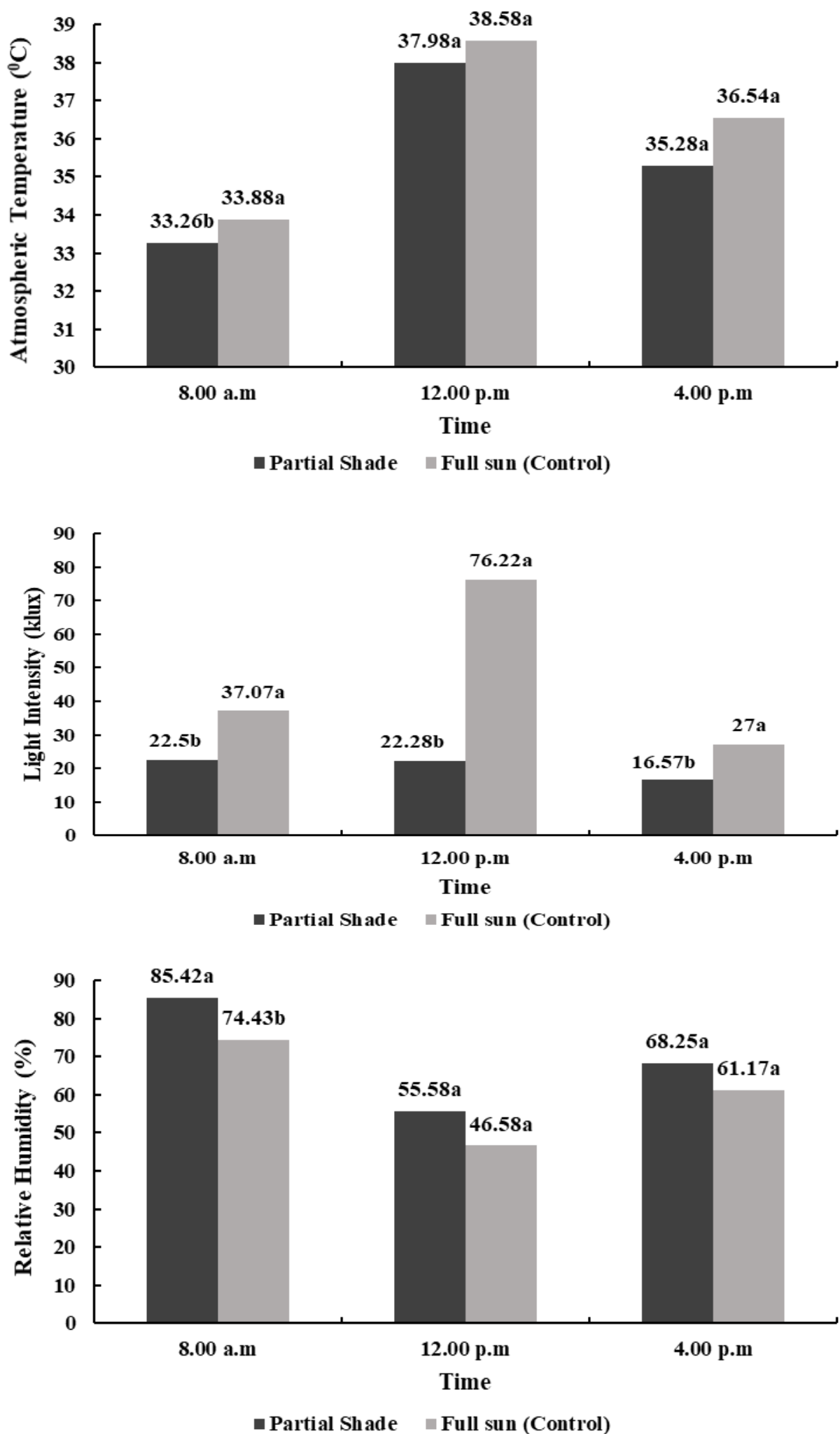

Figure 1. Relationships of atmospheric temperature $\left({ }^{0} \mathrm{C}\right)$, relative humidity $(\%)$ and light intensity (klux) with different time of the day 
Table 2. Effect of shade treatments on weed density and weed dry weight

\begin{tabular}{lcc}
\hline Shade Treatments $(\mathbf{S})$ & $\begin{array}{c}\text { Weed Density } \\
\left(\mathbf{N u m b e r} / \mathbf{m}^{2}\right)\end{array}$ & $\begin{array}{c}\text { Weed Dry Weight } \\
\left(\mathbf{g} / \mathbf{m}^{\mathbf{2}}\right)\end{array}$ \\
\hline Partial Shade & $199.67 \mathrm{a}$ & $9.08 \mathrm{a}$ \\
Full sun (control) & $158.33 \mathrm{~b}$ & $9.56 \mathrm{a}$ \\
\hline
\end{tabular}

Means with the same letter within a given treatment are not significantly different at $p=0.05$

Table 3. Effect of weeding interval treatments on weed density and weed dry weight.

\begin{tabular}{lcc}
\hline Weeding Interval Treatments $(\mathbf{W})$ & $\begin{array}{c}\text { Weed Density } \\
\left(\mathbf{N u m b e r} / \mathbf{m}^{\mathbf{2}}\right)\end{array}$ & $\begin{array}{c}\text { Weed Dry Weight } \\
\left(\mathbf{g} / \mathbf{m}^{\mathbf{2}}\right)\end{array}$ \\
\hline Weeding at one week interval & $94 \mathrm{~d}$ & $1.22 \mathrm{~d}$ \\
Weeding at two week interval & $148 \mathrm{c}$ & $5.66 \mathrm{c}$ \\
Weeding at three week interval & $190 \mathrm{~b}$ & $8.98 \mathrm{~b}$ \\
No weeding (Control) & $284 \mathrm{a}$ & $21.40 \mathrm{a}$ \\
\hline
\end{tabular}

Means with the same letter within a given treatment are not significantly different at $p=0.05$

\subsection{Plant Height}

The results showed that the shade treatments differed significantly regarding plant height throughout the growth stages of chilli (Table 6). These results were comparable to Bibi et al (2012) who reported influence of partial shade on plant height of tomato crop in summer. The tested weeding interval treatments showed highly significant differences in plant height except three and five week after planting (3WAP and 5WAP). The interaction between the shade treatments and weeding interval treatments were insignificant.

\subsection{Number of Leaves}

In terms of the number of leaves, the lowest number at each growth stages was reported in full sun treatment (control) and no weeding treatment (control), showing comparatively poor growth, which resulted in lower plant height and fewer leaves. While the highest leaves were observed in partial shade treatment and one week weeding interval treatment at nine week after planting (9WAP) as $186.04 \mathrm{~cm}$ and $183.58 \mathrm{~cm}$, respectively. A similar pattern was reported by Bibi et al (2012). The interaction between the shade treatments and weeding interval treatments were insignificant. 


\subsection{Leaf Length}

A similar trend was observed in the leaf length resulting in the lowest value being in full sun treatment (control) and the highest in partial shade treatment. No effect of weeding interval treatment was observed but shade treatment showed a significant difference in all growth stages of chilli (Table 6 and 7). Morphological changes such as taller plants and thinner and larger leaves likely enhanced light capture under shaded conditions compared with unshaded plants in bell pepper (Carlos, 2013). The interaction between the shade treatments and weeding interval treatments were insignificant.

\subsection{Yield Variables}

Yield and yield attributes of chilli measured in the study were fruit length, single fruit weight and total yield. The data regarding fruit length are presented in Table 4 and 5. The analysis of variance (ANOVA) showed that the responses of shade treatment and weeding interval treatment had significant effect on fruit size. The interaction between the shade treatment and weeding interval treatment was also significant. The highest single fruit weight was obtained by partial shade treatment and weeding at one week interval treatment. On the other hand the lowest single fruit weight was recorded in full sun (control) and no weeding (control) treatments (Table 4 and 5). Because the adverse environment and weed competition with chilli might be reduce the single fruit weight. The interaction effect between the shade treatments and weeding interval treatments was non-significant. The ultimate aim in chilli cultivation is the economic yield. The data regarding total yield are given in Table 4 and 5 . The ANOVA showed that total yield was significantly affected by shade treatments, weeding interval treatments and interaction between shade and weeding interval treatments. The maximum total yield was recorded in partial shade treatment (3.33 ton/ha) and weeding at one week interval treatment (3.44 ton/ha). The calculated difference in the total yield between partial shade and full sun (control) of 1.05 ton/ha showed the effect of shade and yield increase was $46.05 \%$. Meanwhile, $53.71 \%$ of yield increase was recorded between weeding at one week interval and no weeding (control) treatments.

Table 4. Effect of shade treatments on average fruit length, single fruit weight and total yield

\begin{tabular}{lccc}
\hline Shade Treatments $(\mathbf{S})$ & $\begin{array}{c}\text { Average Fruit } \\
\text { Length }(\mathbf{c m})\end{array}$ & $\begin{array}{c}\text { Single Fruit } \\
\text { Weight }(\mathbf{g})\end{array}$ & $\begin{array}{c}\text { Total Yield } \\
(\mathbf{t} / \mathbf{h a})\end{array}$ \\
\hline Partial Shade & $5.68 \mathrm{a}$ & $2.26 \mathrm{a}$ & $3.33 \mathrm{a}$ \\
Full sun (control) & $4.67 \mathrm{~b}$ & $1.89 \mathrm{~b}$ & $2.28 \mathrm{~b}$ \\
\hline
\end{tabular}

Means with the same letter within a given treatment are not significantly different at $p=0.05$ 
Table 5. Effect of weeding interval treatments on average fruit length, single fruit weight and total yield

\begin{tabular}{|c|c|c|c|}
\hline $\begin{array}{l}\text { Weeding Interval Treatments } \\
\text { (W) }\end{array}$ & $\begin{array}{l}\text { Average Fruit } \\
\text { Length }(\mathbf{c m})\end{array}$ & $\begin{array}{l}\text { Single Fruit } \\
\text { Weight (g) }\end{array}$ & $\begin{array}{l}\text { Total Yield } \\
\quad(\mathrm{t} / \mathrm{ha})\end{array}$ \\
\hline Weeding at one week interval & $5.64 \mathrm{a}$ & $2.66 \mathrm{a}$ & $3.44 \mathrm{a}$ \\
\hline Weeding at two week interval & $5.37 \mathrm{~b}$ & $2.10 \mathrm{~b}$ & $2.93 b$ \\
\hline Weeding at three week interval & $5.13 \mathrm{c}$ & $1.93 b c$ & $2.60 \mathrm{c}$ \\
\hline No weeding (Control) & $4.55 \mathrm{~d}$ & $1.62 \mathrm{c}$ & $2.24 \mathrm{~d}$ \\
\hline
\end{tabular}

Means with the same letter within a given treatment are not significantly different at $p=0.05$

Table 6. Effect of shade treatments on average leaf length, average number of leaves and average plant height

\begin{tabular}{lcccccccccccc}
\hline \multirow{2}{*}{ Shade Treatments (S) } & \multicolumn{4}{c}{ Average Leaf Length (cm) } & \multicolumn{4}{c}{ Average Leaves Number } & \multicolumn{4}{c}{ Average Plant Height (cm) } \\
& 3WAP & 5WAP & 7WAP & 9WAP & 3WAP & 5WAP & 7WAP & 9WAP & 3WAP & 5WAP & 7WAP & 9WAP \\
\hline Partial Shade & $6.18 \mathrm{a}$ & $7.51 \mathrm{a}$ & $10.76 \mathrm{a}$ & $11.68 \mathrm{a}$ & $41.63 \mathrm{a}$ & $58.88 \mathrm{a}$ & $118.83 \mathrm{a}$ & $186.04 \mathrm{a}$ & $35.67 \mathrm{a}$ & $38.42 \mathrm{a}$ & $44.38 \mathrm{a}$ & $49.88 \mathrm{a}$ \\
Full sun (control) & $5.03 \mathrm{~b}$ & $6.4 \mathrm{~b}$ & $6.75 \mathrm{~b}$ & $6.99 \mathrm{~b}$ & $25.33 \mathrm{~b}$ & $32.92 \mathrm{~b}$ & $86.08 \mathrm{~b}$ & $127.25 \mathrm{~b}$ & $24.03 \mathrm{~b}$ & $26.54 \mathrm{~b}$ & $33.38 \mathrm{~b}$ & $42.63 \mathrm{~b}$ \\
\hline
\end{tabular}

Means with the same letter within a given treatment are not significantly different at $p=0.05$ WAP indicates the Week After Planting

Table 7. Effect of weeding interval treatments on average leaf length, average number of leaves and average plant height.

\begin{tabular}{|c|c|c|c|c|c|c|c|c|c|c|c|c|}
\hline \multirow{2}{*}{$\begin{array}{l}\text { Weeding } \\
\text { Treatments (W) }\end{array}$} & \multicolumn{4}{|c|}{ Average Leaf Length (cm) } & \multicolumn{4}{|c|}{$\begin{array}{c}\text { Average Leaves Number } \\
\text { per Plant }\end{array}$} & \multicolumn{4}{|c|}{ Average Plant Height (cm) } \\
\hline & 3WAP & 5WAP & 7WAP & 9WAP & 3WAP & 5WAP & 7WAP & 9WAP & 3WAP & 5WAP & 7WAP & 9WAP \\
\hline Weeding at one week interval & $5.4 \mathrm{a}$ & $6.63 \mathrm{a}$ & $8.5 \mathrm{a}$ & 9.0 & $35.42 \mathrm{a}$ & $51.33 \mathrm{a}$ & $107.75 \mathrm{a}$ & $183.58 \mathrm{a}$ & $31.24 \mathrm{a}$ & $33.88 \mathrm{a}$ & $42.67 \mathrm{a}$ & $51.5 \mathrm{a}$ \\
\hline Weeding at two week interval & $5.88 \mathrm{a}$ & $7.25 \mathrm{a}$ & $8.78 \mathrm{a}$ & $9.55 \mathrm{a}$ & $34.25 \mathrm{a}$ & $46.5 \mathrm{~b}$ & $104.5 \mathrm{a}$ & $165.83 \mathrm{ab}$ & $30.75 \mathrm{a}$ & $33.67 \mathrm{a}$ & $39.42 \mathrm{ab}$ & $47.5 \mathrm{ab}$ \\
\hline Weeding at three week interval & $5.55 \mathrm{a}$ & $7.11 \mathrm{a}$ & $9.1 \mathrm{a}$ & $9.62 \mathrm{a}$ & $34.83 \mathrm{a}$ & $46.0 \mathrm{~b}$ & $99.83 b$ & $147.33 b c$ & $29.28 \mathrm{a}$ & $31.71 \mathrm{a}$ & $37.5 \mathrm{ab}$ & $43.83 \mathrm{bc}$ \\
\hline No weeding (Control) & $5.60 \mathrm{a}$ & $6.81 \mathrm{a}$ & $8.63 \mathrm{a}$ & $9.12 \mathrm{a}$ & $29.42 \mathrm{~b}$ & $39.75 \mathrm{c}$ & $97.75 b$ & $129.83 c$ & $28.13 \mathrm{a}$ & $30.67 \mathrm{a}$ & $35.92 b$ & $42.17 \mathrm{c}$ \\
\hline
\end{tabular}

Means with the same letter within a given treatment are not significantly different at $\mathrm{p}=0.05$ WAP indicates the Week After Planting

\section{Conclusion}

The present study confirmed the favorable benefits of the introduced adaptation package with partial shade and weeding at one week interval with the border crops in terms of improvement of growth, yield and environmental friendliness of chilli cultivation in the dry zone of Sri Lanka. Also, it has significantly enhanced the growth and production performances of chilli. Therefore, providing partial shade with one week interval weeding could be recommended for adoption by the farmers to improve the yield of chilli while promoting lower agro-chemical use, thereby having increased resilience to adverse climatic 
condition and weed infestation in enhanced environmental sustainability especially in the dry regions where chilli is cultivated.

\section{Acknowledgement}

Authors acknowledge the staff members of Department of Agronomy, Faculty of Agriculture, University of Jaffna and Integrated Farm and Training Center, Faculty of Agriculture, University of Jaffna, Kanagarayankulam, Sri Lanka for their assistance.

\section{References}

Bibi, B., Sajid, M., Rab, A., Shah, S., Ali, N., Jan, I., Haq, I., Wahid, F., Haleema, B., \& Ali, I. (2012). Effect of partial shade on growth andn yield of tomato cultivars. Global journal of Biology, Agriculture \& Health, [online] 1(01), 22-26. Available at: http://gifre.org/library/upload/volume/ 22-26-vol-1-1-12-gjbahs.pdf, Accessed 21 Jul. 2017.

Bote, A., \& Struik, P. (2011). Effects of shade on growth, production and quality of coffee (Coffea arabica) in Ethiopia. Journal of Horticulture and Forestry, 3(11), 336-341.

Carlos, J. (2013). Bell Pepper (Capsicum annum L.) Crop as Affected by Shade Level: Microenvironment, Plant Growth, Leaf Gas Exchange, and Leaf Mineral Nutrient Concentration. HORT SCIENCE, 48(2), 175-182.

Dishani, P., \& De Silva, C. (2015). Will the dry zone farmers cope with climate change impacts? -A case study in Hambantota District. In: Annual Academic Sessions. Open University of Sri Lanka.

Eeswaran, R., Costa, W. A. J. M. D., Costa, D. M. D., Dandeniya, W. S., Sivakumar, S., \& Suriyagoda, L. D. B. (2016). Evaluation of a climate change-adaptive, eco-friendly agronomic package for potato (Solanum tuberosum) cultivation in the farmer fields of the Jaffna district of Sri Lanka. Tropical Agricultural Research, 27(2), 190-202. https://doi.org/10.4038/tar.v27i2.8167

Eeswaran, R., Costa, W. A. J. M. D., Costa, D. M. D., Dandeniya, W. S., Suriyagoda, L. D. B., Sivakumar, S., \& Arasakesary, S. J. (2015). Performance of a climate change - resilient agronomic package for chilli (Capsicum annuum L.) in comparison to the existing crop management in the Northern Province of Sri Lanka. Jaffna, Proceedings of International Conference on Dry Zone Agriculture, October 2016, 32-33.

G/Mariam, E., \& Fufa, A. (2016). Effect of Different Time and Frequency of Weeding on Castor (Ricinus Communis L.) in Central Rift Valley of Ethiopia. International Journal of Research in Agriculture and Forestry, 3(7), 31-37.

Godawatte, V. N. A., Silva, C. S. D., \& Gunawardhana, M. D. M. (2011). Effect of Mulch on Growth and yield of Chilli (Capsicum annuum 1.) to cope with global temperature stress due to climate change. In: International Conference on the Impact of Climate Change on Agriculture. Mapalana Kamburupitiya: University of Ruhuna, 95-102. 
Gunawardena, M. D. M., \& Silva, C. S. D. (2014). Identifying the Impact of Temperature and Water Stress on Growth and Yield Parameters of Chilli (Capsicum annuum L.). OUSL Journal, 7, 25-42.

Orobiyi, A., Loko, Y., Assogba, P., Akouègninou, A., Vodouhè, R., Dansi, A., Sanni, A., \& Dansi, M. (2013). Chili (Capsicum annuum L.) in southern Benin: production constraints, varietal diversity, preference criteria and participatory evaluation. International Research Journal of Agricultural Science and Soil Science, 3(4), 107-120.

Ramesh, K., Matloob, A., Aslam, F., Florentine, S., \& Chauhan, B. (2017). Weeds in a Changing Climate: Vulnerabilities, Consequences, and Implications for Future Weed Management. Frontiers in Plant Science, 8, 1-12. https://doi.org/10.3389/fpls.2017.00095

Sarkar, N., Maiti, R., Singh, V., \& Purohit, S. (2007). Research advances in capsicum pepper (Capsicum annuum L) and other species. Jodhpur: Agrobios (International), 1-5.

Wheeler, T., Craufurd, P., Ellis, R., Porter, J., \& Vara Prasad, P. (2000). Temperature variability and the yield of annual crops. Agriculture, Ecosystems \& Environment, 82(2000), 159-167. Available at:

https://pdfs.semanticscholar.org/570b/e3cba329a1b2a9c0db3c9ed01f48e6dd92b6.pdf, accessed $21^{\text {st }}$ January 2018.

\section{Copyright Disclaimer}

Copyright for this article is retained by the author(s), with first publication rights granted to the journal.

This is an open-access article distributed under the terms and conditions of the Creative Commons Attribution license (http://creativecommons.org/licenses/by/4.0/). 